\title{
Studies on Stem Cuttings of Kiwi (Actinidia chinensis PL. CV Bruno)
}

\author{
Elizabeth O. Ono $^{1 *}$, João D. Rodrigues ${ }^{1}$ and Sheila Z. de Pinho ${ }^{2}$ \\ ${ }^{1}$ Departamento de Botânica - Instituto de Biociências - Universidade Estadual Paulista - UNESP - CEP 18.618- \\ 000 - Botucatu (SP), ${ }^{2}$ Departamento de Bioestatística - Instituto de Biociências - Universidade Estadual Paulista - \\ UNESP - CEP 18.618-000 - Botucatu - SP, Brasil
}

\begin{abstract}
The work was carried out to study the effects of some auxins and boron in the rooting of kiwi (Actinidia chinensis Planch cv Bruno) stem cuttings.. These cuttings were treated on the base individually with $\mathrm{H}_{2} \mathrm{O} ; \mathrm{NAA} 300 \mathrm{mg} . \mathrm{L}^{-1}$; IBA $300 \mathrm{mg} . \mathrm{L}^{-1}$; NAA $300 \mathrm{mg} \cdot \mathrm{L}^{-1}+$ Boron; IBA $300 \mathrm{mg} \cdot \mathrm{L}^{-1}+$ Boron; NAA 0,5\%-talc and IBA 0,5\%-talc. After the treatments, the cuttings were placed in styrofoam trays with vermiculite under moist conditions for 120 days. The evaluation of auxin and boric acid effects were made by observing rooted stem cuttings percentage; reducing and total sugar analysis ( $\mathrm{g} / 100 \mathrm{~g}$ of dry matter); and tryptophan analysis (in $\mu \mathrm{g} / 100 \mathrm{mg}$ of dry matter). The effects of such treatments were observed during four seasons of the year. The results showed that summer season was the best for rooting. Use of IBA or NAA in the cuttings showed to be unnecessary.
\end{abstract}

Key words: Actinidia chinensis, NAA, IBA, boron, rooting

\section{INTRODUCTION}

Kiwi multiplication is generally carried out through sexual reproduction and by vegetative propagation using stems and roots for new plants. The propagation for stem cuttings is the usual method for the multiplication of that species (Bosman \& Uys, 1978). In the multiplication through hardwood cuttings low rooting percentage were observed. On the other hand, in the propagation for semihardwood cuttings up to $90 \%$ of rooting were observed. Thus, this method could be used for fast multiplication of that species (Bosman \& Uys, 1978).

Hartmann et al. (1997) reported that the auxins stimulated and speeder up the cutting's rooting. Lewis (1980) emphasized a metabolic relationship between the boron, phenolic composites and peroxidases/IAA-oxidases, which interacted with each one and with the auxins. The relation between boron, auxin and peroxidase/IAA-oxidase activity are contradictory. For example, lack of boron increased the peroxidase activity in many tissues, but reduced in some other tissues (Dutta $\&$ Mc Ilrath, 1964). The IAA-oxidase activity was also reported to be increased by boron (Parish, 1968).

Some authors related the influence of the season on the cutting's rooting. The variation in the rooting capacity was attributed to the plant growth phases (Mercado Flores \& Kester, 1966) and to the cuttings biochemical state (Basu et al., 1973).

The purpose of the work was to study the effect of auxins and boron in the rooting of kiwi stem cuttings, aiming at the posterior new plant production.

\section{MATERIAL AND METHODS}

Cuttings of semihardwood kiwi (Actinidia chinensis Planch cv Bruno) branches were used with two nodes and two leaves cut in half with approximately $10 \mathrm{~cm}$ of length. Approximately,

\footnotetext{
* Author for correspondence
} 
$1 \mathrm{~cm}$ of cuttings base was treated with IBA $0.5 \%$ - powder and NAA $0.5 \%$ - powder in the talc form. The IBA at $300 \mathrm{mg} . \mathrm{L}^{-1}$ was dissolved in alcohol and the solution was completed with distilled water. For the treatments with auxins plus boric acid, the latter was dissolved in the solution of NAA or IBA at $150 \mathrm{mg} / \mathrm{ml}$. After that, $2.5 \mathrm{~cm}$ of the cuttings base was immersed in these solutions for approximately 24 hours.

The combinations between auxins and boric acid were carried out through the following treatments: $\mathrm{H}_{2} \mathrm{O}$ (control); NAA $300 \mathrm{mg} . \mathrm{L}^{-1}$; IBA $300 \mathrm{mg} . \mathrm{L}^{-1}$; NAA $300 \mathrm{mg} . \mathrm{L}^{-1}+\mathrm{B}$; IBA $300 \mathrm{mg} . \mathrm{L}^{-1}+\mathrm{B}$; NAA 0.5\%-powder and IBA $0.5 \%$-powder.

After the treatments, the cuttings was placed in styrofoam trays with vermiculite and placed under moist conditions for 120 days. The evaluation of auxins and boric acid effects on the rooting of kiwi stem cuttings was carried out through the followings: the rooted cuttings percentage; $b$. reducing and total sugars analysis $(\mathrm{g} / 100 \mathrm{~g}$ of dry matter) and c. tryptophan analysis ( $\mu \mathrm{g} / 100 \mathrm{mg}$ of dry matter).

The biochemical evaluations was carried out in cuttings' samples before being placed in the rooting medium and after, at the time of the evaluation same them.

All the seven treatments was tested during 4 different times (months), corresponding to spring, summer, autumn and winter. This was carried with a purpose to select the best havest time for the cuttings' collect of kiwi branches, aiming at higher rooting success.

The determination of reducing and total sugars was carried by the Somogy-Nelson method (Nelson, 1944) for dry samples. The method for the tryptophan determination was as described in the Plant Biochemistry Laboratory of the CENA/USP (Kersten, 1990).

The entirely randomized design with 7 treatments at each season with 2 replications was utilized. Each parcel had 16 cuttings. The results for rooted cuttings percentage were been submitted to the variance analysis ( $\mathrm{F}$ test) at the time of summer, autumn and winter (data transformed into arc sen $\left.\sqrt{ }^{-}(\mathrm{x} / 100)\right)$ and the averages were compared through the Tukey test with $5 \%$ of probability. The data for spring time not analyzed due to the high number of null values.

\section{RESULTS AND DISCUSSION}

The results of kiwi cv Bruno cuttings' rooting percentage are shown in Table 1. The branches' cuttings collected in the spring had lower rooted cuttings indicating to be unfavorable period for the collection and the cuttings production. Kiwi cuttings collected in the summer that had not received treatment (control) had the highest rooting percentage. Cuttings that had received treatment with $300 \mathrm{IBA}$ mg. $\mathrm{L}^{-1}+\mathrm{B}$ showed high rooting percentage. Boron addition to the auxins solutions increased the rooting percentage at this time of evaluation.

The treatment with NAA $300 \mathrm{mg} \cdot \mathrm{L}^{-1}+\mathrm{B}$ showed higher percentage of rooted cuttings, in the autumn collect but without significance difference. Control cuttings and those treated with IBA $0.5 \%$-powder were the most effective treatments in the rooting of kiwi branches cuttings collected in the winter. Morever, it also did not produced cuttings with high rooting potentiality.

Lawes \& Yes (1980) reported fast roots formation in cuttings collected in the summer similar observation were made by Poves (1982). Costa \& Baraldi (1983) and Vitagliano et al. (1983) observed low rooting percentage in cuttings collected in the summer. In the present work, however the best time of kiwi branches collect for the cuttings production was the summer.

The boron addition had influence in the rooting percentage increase only in the cuttings of branches collected in the summer. In the attempt to discover the action of boron in the rooting of cuttings, some works have been carried out. Gauch \& Dugger (1953) considered the existence of a direct control of the carbohydrate movement for boron, claiming that this forms a ionizable complex boron-sacarose, facilitating the carbohydrate transport through the membranes, being translocated quickly for the 
places where celullar development and elongating occur.

Some authors reported that the roots in stem cuttings of plants are initiated by the auxin requiring growth or being this, extremely increased for boron (Middleton et al., 1980). According to Esau (1965), the roots originate endogenously from pericycle or the endoderm, together to the vascular cambium, where the boron has its primary role activating the meristematics cells (Lewis, 1980). In the present work, boron addition influenced positively in the rooting process of kiwi branches cuttings collected during the summer.

It was not possible to differentiate the effectiveness between NAA or IBA on the rooting. Aparently, the two auxins behaved similarly.

Table 1. Rooting percentage average of kiwi (Actinidia chinensis Pl. cv Bruno) stem cuttings collected during four seasons.

\begin{tabular}{|c|c|c|c|c|c|}
\hline \multirow[t]{2}{*}{ Treatments } & \multicolumn{4}{|c|}{ Seasons } & \multirow[b]{2}{*}{$\mathrm{x}$} \\
\hline & Spr. & Sum & Aut. & Win & \\
\hline $\mathrm{H}_{2} \mathrm{O}$ & 10,0 & $55,6 \mathrm{a}$ & 17,5 & 23.1 & 26,6 \\
\hline NAA $300 \mathrm{mg} \cdot \mathrm{L}^{-1}$ & 0 & $11,1 \mathrm{ab}$ & 12,5 & 3.9 & 6,9 \\
\hline IBA $300 \mathrm{mg} . \mathrm{L}^{-1}$ & 0 & $11,1 \mathrm{~b}$ & 20,0 & 3.9 & 8,8 \\
\hline NAA $300 \mathrm{mg} \cdot \mathrm{L}^{-1}+\mathrm{B}$ & 0 & $44,4 \mathrm{ab}$ & 25,0 & 7.7 & 19,3 \\
\hline IBA $300 \mathrm{mg} \cdot \mathrm{L}^{-1}+\mathrm{B}$ & 0 & $50,0 \mathrm{ab}$ & 17,5 & 0 & 16,9 \\
\hline NAA 0,5\%-pó & 0 & $11,1 \mathrm{ab}$ & 15,0 & 7.7 & 8,5 \\
\hline AIB 0,5\%-pó & 7,5 & $33,3 \mathrm{ab}$ & 22,5 & 23.1 & 21,6 \\
\hline $\mathrm{x}$ & 2,5 & 31,3 & 18,6 & 9.9 & - \\
\hline $\mathrm{F}$ & - & $6.39 *$ & 0.65 & 0,80 & \\
\hline C.V. & & 23.3 & 21.6 & 82.6 & \\
\hline
\end{tabular}

* significance to the $5 \%$ probability

average followed by same letter in the column did not differ significantly for the Tukey test

Table 2. Reducing sugars contents ( $\mathrm{g} / 100 \mathrm{~g}$ of dry matter) in kiwi (Actinidia chinensis $\mathrm{Pl}$. cv Bruno) stem cuttings before and after the branches treatments' collected during four seasons.

\begin{tabular}{|c|c|c|c|c|c|}
\hline \multirow[t]{2}{*}{ Treatments } & \multicolumn{4}{|c|}{ Seasons } & \multirow[b]{2}{*}{$\mathrm{x}$} \\
\hline & Spr. & Sum & Aut. & Win & \\
\hline before treatments & $0.93 \mathrm{Cb}$ & $0.64 \mathrm{Cc}$ & $1.57 \mathrm{Be}$ & $5.37 \mathrm{Aa}$ & 2.13 \\
\hline $\mathrm{H}_{2} \mathrm{O}$ & $1.91 \mathrm{Aa}$ & 1.65 Bab & $3.62 \mathrm{Ab}$ & $1.20 \mathrm{Cbc}$ & 2.10 \\
\hline NAA $300 \mathrm{mg} \cdot \mathrm{L}^{-1}$ & $2.00 \mathrm{Ba}$ & $1.46 \mathrm{Cb}$ & $3.20 \mathrm{Abc}$ & $0.99 \mathrm{Dc}$ & 1.91 \\
\hline IBA 300mg. $\mathrm{L}^{-1}$ & $1.91 \mathrm{Ba}$ & $1.76 \mathrm{BCab}$ & 2.89 Acd & $1.49 \mathrm{Cb}$ & 2.01 \\
\hline NAA $300 m g . L^{-1}+B$ & $2.00 \mathrm{Ba}$ & $1.70 \mathrm{BCab}$ & $4.18 \mathrm{Aa}$ & $1.46 \mathrm{Cbc}$ & 2.33 \\
\hline IBA $300 \mathrm{mg} \cdot \mathrm{L}^{-1}+\mathrm{B}$ & $1.91 \mathrm{Ba}$ & $1.50 \mathrm{Cb}$ & $4.57 \mathrm{Aa}$ & $1.49 \mathrm{Cb}$ & 2.37 \\
\hline NAA 0,5\%-pó & $1.91 \mathrm{Ba}$ & $2.00 \mathrm{Ba}$ & $2.57 \mathrm{Ad}$ & $1.46 \mathrm{Cbc}$ & 1.98 \\
\hline AIB 0,5\%-pó & $2.00 \mathrm{Aa}$ & $2.00 \mathrm{Aa}$ & $1.11 \mathrm{Be}$ & $1.16 \mathrm{Bbc}$ & 1.57 \\
\hline $\mathrm{x}$ & 1.82 & 1.59 & 2.96 & 1.83 & - \\
\hline $\mathrm{F}$ treatments $(\mathrm{T})=$ & $22.79 *$ & $\mathrm{~F}$ season $(\mathrm{S})=$ & $273.25 *$ & $\mathrm{FT} \times \mathrm{S}=$ & $106.43 *$ \\
\hline
\end{tabular}

* significance to the $5 \%$ probability

average followed by same letter in the column did not differ significantly for the Tukey test 
Results with the treatments with NAA 0.5\%powder and IBA 0.5\%-powder showed that these growth regulators had been more effective in solution. In the talc form, the IBA was more effective than the NAA.

The results for content of reducing and total sugars in the kiwi cuttings before and after the treatments are shown in Tables 2 and 3, respectively. During winter higher amount of reducing and total sugars were observed, before of the rooting cuttings beginning process. Results showed that after the rooting process, increase in the content of reducing and total sugars occurred during the spring, summer and autumn cuttings. In contrast, in cuttings during the winter a reduction in their concentration was observed, indicating perhaps, consumption of those substances. Therefore, these observations indicated that the auxins treatments increased reducing and total sugars in the cuttings, possibly for leaves transport or conversion.

According to Veierskov et al. (1976), the auxin has an important role in the roots initiation. Other substances also showed important performance, mainly the sugars. The relation between auxins and carbohydrates in the roots development seems complex; however, the auxin can influence directly in the basal carbohydrates accumulation as well as due to increase of its concentration, conditions that induce the rooting (Altman \& Wareing, 1975).

The content of reducing and total sugars, apparently, had not influenced in the rooting percentage improvement. The content of reducing and total sugars, in cuttings of autumn and winter, more had been raised previously to the rooting process; however, at those seasons not presented high rooting percentage.

According to Hess (1969) the carbohydrates do not increase the rooting reply, but they are a source of carbon and energy for the synthesis of other essential substances for the roots formation. According to Brutsch (1971) the carbohydrates availability in the cuttings was, probably the factor that determines the rooting potential in the Carya illinoensis (Wang.) C. Koch cuttings. During the development of the primordium root, the content of free sugars in the cutting bases many time, increased due to starch hydrolysis or had to the increase of the basipetal sugars transport, or both (Altman \& Wareing, 1975). The endogenous or exogenous auxin increases starch hydrolysis (Davis \& Potter, 1981).

The results for tryptophan content in kiwi cuttings are presented in Table 4. It can be seen that tryptophan contents reduced in

Table 3. Total sugar average contents (g/100 g of dry matter) in kiwi (Actinidia chinensis Pl. cv Bruno) stem cuttings before and after the branches treatments' collected during four seasons.

\begin{tabular}{|c|c|c|c|c|c|}
\hline \multirow[t]{2}{*}{ Treatments } & \multicolumn{4}{|c|}{ Seasons } & \multirow[b]{2}{*}{$\mathrm{x}$} \\
\hline & Spr. & Sum & Aut. & Win & \\
\hline before treatments & $2.93 \mathrm{Bb}$ & $2.22 \mathrm{Cb}$ & $1.89 \mathrm{Cf}$ & $6.00 \mathrm{Aa}$ & 3,26 \\
\hline $\mathrm{H}_{2} \mathrm{O}$ & $2.22 \mathrm{Bc}$ & $0.90 \mathrm{Cd}$ & $5.99 \mathrm{Ad}$ & $1.32 \mathrm{Ce}$ & 2.61 \\
\hline NAA $300 \mathrm{mg} \cdot \mathrm{L}^{-1}$ & $3.52 \mathrm{Bab}$ & $1.38 \mathrm{Ccd}$ & $9.80 \mathrm{Aa}$ & $1.79 \mathrm{Ce}$ & 4.12 \\
\hline IBA $300 \mathrm{mg} . \mathrm{L}^{-1}$ & $3.52 \mathrm{Bab}$ & $3.70 \mathrm{Ba}$ & $9.80 \mathrm{Aa}$ & $2.48 \mathrm{Ccd}$ & 4.88 \\
\hline NAA $300 \mathrm{mg} \cdot \mathrm{L}^{-1}+\mathrm{B}$ & $3.82 \mathrm{Ba}$ & $1.58 \mathrm{Dc}$ & $4.80 \mathrm{Ae}$ & $2.60 \mathrm{Cc}$ & 3.20 \\
\hline IBA 300mg. $\mathrm{L}^{-1}+\mathrm{B}$ & $3.82 \mathrm{Ba}$ & $1.69 \mathrm{Cbc}$ & $9.01 \mathrm{Ab}$ & $3.52 \mathrm{Bb}$ & 4.51 \\
\hline NAA 0,5\%-pó & $3.52 \mathrm{Bab}$ & $4.00 \mathrm{Ba}$ & $8.14 \mathrm{Ac}$ & $1.90 \mathrm{Cde}$ & 4.39 \\
\hline IBA 0,5\%-pó & $3.40 \mathrm{Bab}$ & 1.47 Dcd & $5.19 \mathrm{Ae}$ & $2.87 \mathrm{Cc}$ & 3.23 \\
\hline $\mathrm{X}$ & 3.35 & 2.12 & 6.83 & 2.81 & - \\
\hline $\mathrm{F}$ treatments $(\mathrm{T})=$ & $144.34 *$ & F season $(\mathrm{S})=$ & $1970.22 *$ & $\mathrm{FT} \times \mathrm{S}=$ & $170.45^{*}$ \\
\hline C.V. $(\%)=19.54$ & & & & & \\
\hline
\end{tabular}


Table 4. Tryptophan average contents (mg/100 g of dry matter) in kiwi (Actinidia chinensis Pl. cv Bruno) stem cuttings before and after the branches treatments' collected during four seasons.

\begin{tabular}{|c|c|c|c|c|c|}
\hline \multirow[t]{2}{*}{ Treatments } & \multicolumn{4}{|c|}{ Seanos } & \multirow[b]{2}{*}{$\mathrm{x}$} \\
\hline & Spr. & Sum & Aut. & Win & \\
\hline before treatments & $0.1125 \mathrm{Aa}$ & $0.1120 \mathrm{Aa}$ & $0.1040 \mathrm{Aa}$ & $0.1025 \mathrm{Aa}$ & 0.1078 \\
\hline $\mathrm{H}_{2} \mathrm{O}$ & $0.0055 \mathrm{Bb}$ & $0.0040 \mathrm{Bb}$ & $0.0125 \mathrm{ABbc}$ & $0.0200 \mathrm{Abc}$ & 0.0105 \\
\hline NAA $300 \mathrm{mg} \cdot \mathrm{L}^{-1}$ & $0.0155 \mathrm{ABb}$ & $0.0090 \mathrm{Bb}$ & $0.0165 \mathrm{ABb}$ & $0.0280 \mathrm{Abc}$ & 0.0173 \\
\hline IBA $300 \mathrm{mg} . \mathrm{L}^{-1}$ & $0.0080 \mathrm{Bb}$ & $0.0070 \mathrm{Bb}$ & $0.0090 \mathrm{Bbc}$ & $0.0225 \mathrm{Abc}$ & 0.0116 \\
\hline NAA $300 \mathrm{mg} \cdot \mathrm{L}^{-1}+\mathrm{B}$ & $0.0045 \mathrm{Bb}$ & $0.0010 \mathrm{Bb}$ & $0.0010 \mathrm{Bc}$ & $0.0290 \mathrm{Abc}$ & 0.0089 \\
\hline IBA 300mg. $\mathrm{L}^{-1}+\mathrm{B}$ & $0.0045 \mathrm{Bb}$ & $0.0025 \mathrm{Bb}$ & $0.0045 \mathrm{Bbc}$ & $0.0340 \mathrm{Ab}$ & 0.0114 \\
\hline NAA 0,5\%-pó & $0.0050 \mathrm{ABb}$ & $0.0135 \mathrm{ABb}$ & $0.0035 \mathrm{Bbc}$ & $0.0170 \mathrm{Ac}$ & 0.0098 \\
\hline IBA 0,5\%-pó & $0.0060 \mathrm{Bb}$ & $0.0020 \mathrm{Bb}$ & $0.0110 \mathrm{Bbc}$ & $0.0325 \mathrm{Ab}$ & 0.0129 \\
\hline $\mathrm{x}$ & 0.0202 & 0.0189 & 0.0203 & 0.0357 & - \\
\hline $\mathrm{F}$ treatments $(\mathrm{T})=$ & $430.44 *$ & $\mathrm{~F}$ season $(\mathrm{S})=$ & $47.36^{*}$ & $\mathrm{FT} \times \mathrm{S}=$ & $4,32 *$ \\
\hline C.V. $(\%)=19.54$ & & & & & \\
\hline
\end{tabular}

all the studied seasons and treatments. Tryptophan content in the cuttings of branches collected at the 4 different seasons did not differ significantly. It was also observed, that independent of the treatments during the process of roots initiation the reduction in tryptophan content was higher in the cuttings of branches collected during the spring, summer and autumn when compared with the those collected during the winter.

Singh (1981) suggested tryptophan as the precursor in the indolacetic acid biosynthesis. Middleton et al. (1980) and Jarvis \& Booth (1981) reported that the exogenous application of indol-butyric acid to the cuttings base increased the level of indolacetic acid in leaves.

Samish \& Spiegel (1957) noted high percentage of tryptophan and total protein in grapevine cuttings (Vitis vinifera L.), suggesting that the auxins addition occurred, from the accumulated tryptophan.

\section{CONCLUSION}

The results on the kiwi (Actinidia chinensis Planch. cv Bruno) stem cuttings rooting process showed summer as the best season for cuttings' without necessity of auxin treatments.

\section{RESUMO}

O presente trabalho teve como objetivo, estudar o efeito de auxinas sintéticas e do boro, sobre o enraizamento de estacas caulinares de kiwi (Actinidia chinensis Planch. cv Bruno). As estacas continham dois nós com aproximadamente $10 \mathrm{~cm}$ de comprimento, contendo 2 folhas cortadas ao meio. As bases das estacas receberam os seguintes tratamentos: control $\left(\mathrm{H}_{2} \mathrm{O}\right)$; NAA 300 mg. $\mathrm{L}^{-1}$; IBA 300 mg. $\mathrm{L}^{-}$ ${ }^{1}$; NAA $300 \mathrm{mg} \cdot \mathrm{L}^{-1}+\mathrm{B}$; IBA $300 \mathrm{mg} \cdot \mathrm{L}^{-1}+\mathrm{B}$; NAA 0,5\%-pó e IBA 0,5\%-pó. Após os tratamentos as estacas foram plantadas em bandejas de enraizamento contendo vermiculita pura e colocadas em câmara de nebulização por 120 dias até a coleta das mesmas. Para a avaliação do efeito das auxinas e boro, foram realizadas as seguintes observações: 1 . porcentagem de estacas enraizadas; 2. análise de açúcares redutores e açúcares totais (em $\mathrm{g} / 100 \mathrm{~g}$ de matéria seca); 3 . análise de triptofano (em $\mu \mathrm{g} / 100 \mathrm{mg}$ de matéria seca). Além disso, foram verificados o efeito dos tratamentos em quatro épocas, que corresponderam às estações do ano (primavera, verão, outono e inverno). Através dos resultados obtidos no processo de enraizamento de estacas caulinares de kiwi (Actinidia chinensis Planch. cv Bruno), concluise ser o verão a melhor época de coleta dos ramos para a produção das estacas sem a necessidade do tratamento com auxinas.

\section{REFERENCES}


Altman, A. \& Wareing, P.F. (1975), The effect of IAA on sugar accumulation and basipetal transport of ${ }^{14} \mathrm{C}$-labelled assimilates in relation to root formation in Phaseolus vulgaris cuttings. Physiol. Plant., 33, 32-38.

Basu, R.N.; Mandal, K.; Choudhary, G.K. (1973), Activity of the IAA-synthetising system in relation to synergism between auxins and non-auxinic chemicals in rooting of cuttings. Indian J. Plant Physiol., 16, 5056.

Bosman, D.C. \& Uys, D.C. (1978), Propagation of kiwifruit from softwood cuttings. Decidous Fruit Grower, 28, 334-336.

Brutsch, M.O. (1971), Rooting and early growth of Carya illinoensis (Wang.) K. Koch stem cuttings. M.Sc. Thesis, University of Natal, Pietermaritzburg.

Costa, G. \& Baraldi, R. (1983a), Ricerche sulla propagazione per talea legnosa dell Actinidia chinensis. Riv. Ortoflorofruticolt. Ital., 67, 123-128.

Davis, T.D. \& Potter, J.R. (1981), Current photosynthate as a limiting factor in adventitious root formation on leafy pea cuttings. J. Amer. Soc. Hortic. Sci., 106, 278-282.

Dutta, T.R. \& Mc Ilrath, W.J. (1964), Effects of boron on growth and lignification in sunflower tissue. Bot. Gaz., 125, 89-91.

Epstein, E. \& Lavee, S. (1983), Conversion of IBA to IAA by cuttings of grapevine and olive. Plant Physiol., 72, 116-118.

Esau, K. (1965), Plant anatomy. John Willey and Sons, New York.

Gauch, H.G. \& Dugger, W.M. (1953), The role of boron in the translocation of sucrose. Plant Physiol., 28, 457-466.

Hartmann, H.T.; Kester, D.E.; Davies Jr., F.T. (1997), Plant propagation; principles and practices. Englewood Clipps/ Prentice-Hall, New York.

Hess, C.E. (1969), Internal and external factors regulating root initiation; root growth. Buttersworth London.

Jarvis, B.C. \& Booth, A. (1981), Influence of indolebutyric acid, boron, myo-inositol, vitamin $\mathrm{D}_{2}$ and seedling age on adventitious root development in cuttings of Phaseolus aureus. Physiol. Plant., 3, 213-218.
Kersten, E. (1990), Efeito do boro, zinco e ácido indol-butírico no enraizamento de estacas de dois cultivares de ameixeira (Prunus salicina Lindl.). PhD Thesis, Escola Superior de Agricultura "Luiz de Queiroz", Universidade de São Paulo, Piracicaba, Brazil.

Lawes, G.S. \& Sim, B.L. (1980), An analysis of factors affecting the propagation of kiwifruit. Orchardist New Zealand, 53, 88-90.

Lewis, D.H. (1980), Boron, lignification and the origin of vascular plants - a unified hypothesis. New Phytol., 84, 209-229.

Mercado Flores, I. \& Kester, D.E. (1966), Factors affecting the propagation of some interspecific hybrids of almond by cuttings. Proc. Am. Soc. Hortic. Sci., 88, 224-231.

Middleton, W.; Jarvis, B.C.; Booth, A. (1980), The role of leaves in auxin and borondependent rooting of stem cuttings of Phaseolus aureus Roxb. New Phytol., 84, 251-259.

Nelson, N. (1944), A photometric adaptation of the Somogy method for determination of glucose. J. Biol. Chem., 153, 375-380.

Parish, R.W. (1968), In vitro studies on the relationship between boron and peroxidase. Enzymologia, 35, 239-252.

Poves, L.T. (1982), El kiwi o Actinidia. Hojas Divulgadoras del Ministerio de Agricultura, Pesca y Alimentacion, Madrid.

Samish, R.M. \& Spiegel, P. (1957), The influence of the nutrition of the mother vine of the rooting of cuttings. Ktavin, 8, 93-100.

Singh, M. (1981), Effect of zinc, phosphorus ad nitrogen on tryptophan concentration in rice grains grown on limed and unlimed soils. Plant Soil, 62, 305-308.

Veierskov, B.; Hansen, J.; Andersen, A.S. (1976), Influence of cotyledon excision and sucrose on root formation in pea cuttings. Physiol. Plant., 36, 105-109.

Vitagliano, C.; Testolini,R.; Youssef, J. (1983), Osservazioni su alcuni fattori influenzanti la rizogenesi di talee legnose e semi-legnose di Actinidia (Actinidia chinensis Planch.). Paper presented at $2^{\text {th }}$ Incontro Frutticolo Sull Actinidia.

Received: December 17, 1997; Revised: March 29, 1998; Accepted: August 06, 1999. 